ks. Stanisław Pisarek

\title{
Lidia - pierwsza Europejka ochrzczona przez św. Pawła Apostoła
}

Martyrologium Romanum ${ }^{1}$ podaje pod datą 3 sierpnia wspomnienie św. Lidii. Ta pierwsza kobieta, którą św. Paweł ochrzcił po przybyciu do Europy, zasługuje w czasie jednoczenia się naszego kontynentu na szczególną promocję. Wiemy o niej z Dziejów Apostolskich [16, 11-15. 40]. Ks. Józef Gawor, redaktor GN był wielkim miłośnikiem Pisma Świętego i pilnym jego czytelnikiem. Jemu zawdzięczamy to, że z okazji Sacrum Poloniae Millennium obchodzonym w roku 1966, na głównych drzwiach do katowickiej katedry Chrystusa Króla, wówczas ufundowanych, wśród najsławniejszych scen chrztu świętego z historii zbawienia [z Biblii i historii chrześcijaństwa] znalazła się także scena chrztu Lidii, w mieście macedońskim Filippi około roku 50, z rąk św. Pawła Apostoła razem z jej domem przyjętego $^{2}$. Ks. Gawor był tu poniekąd wizjonerem, jakby przeczuwał nasze dni zmagania się o umieszczenie invocatio Dei w preambule powstającej konstytucji zjednoczonej Europy; by była Europą Ducha winna oprzeć się na swoim wielkim dziedzictwie chrześcijańskim. To on nazwał prawie pół wieku temu Lidię z Filippi matka chrzestna Europy.

Kim była Lidia? Pochodziła z Tiatyry położonej w Azji Mniejszej, na obszarze dzisiejszej Turcji. Jako pobożna Żydówka czciła jednego, prawdziwego Boga $^{3}$. Mógł to być stary przekaz, który przylegał do niej, jako że w Tiatyrze, co poświadcza Józef Flawiusz, pisarz żydowski, istniała kolonia żydowska. To, że uczestniczyła ona w spotkaniu modlitewnym nad rzeką w szabat, sugeruje, że nie było w Filippi wystarczającej liczby Żydów mężczyzn [fachowym

${ }^{1}$ H. Fros, Wspomnienie świętych na każdy dzień roku. Martyrologium, Kraków 1992, s. 155.

${ }^{2}$ Profesor J. Gnilka odbył podróż naukową po śladach Pawła. Zdjęcia z niej umieścił w monografii: Paulus von Tarsus - Apostel und Zeuge, Freiburg im Breisgau 1996. Zobacz tamże jego zdjęcie: Tradycyjne miejsce chrztu Lidii nad Gangitesem koło Filippi, pomiędzy s. 64 a 65 .

${ }^{3} \mathrm{BT}^{5}, 2000$, ss. 1441,1445 n, sugeruje w przypisie do Dz 13, 16, że byłaby ona z nawróconych na monoteizm pogan, którzy nie przestrzegali jeszcze wszystkich przepisów Prawa, chociaż uczestniczyli w niektórych nabożeństwach. 
określeniem na to jest minjan $=10$ mężczyzn], dla wymaganego quorum do założenia właściwej synagogi. Widzimy tu subtelny, lecz ważny punkt, na który Łukasz chce zwrócić uwagę, iż Lidia nie mogąc być członkiem założycielem synagogi żydowskiej, mogła być i jest pierwszą nawróconą na chrześcijaństwo Europejką i jest faktycznie członkiem założycielem wspólnoty chrześcijańskiej, która zaczyna się spotykać w jej domu [Dz 16, 40]. Kobiety żydowskie w diasporze, uczestniczyły w hellenistycznym odrodzeniu i mogły tworzyć swoje własne grupy religijne i odbywać spotkania dla sprawowania liturgii lub modlitw; ten przypadek ma miejsce w naszym opowiadaniu zapisanym w Dziejach Apostolskich. Niemniej, nie jest oczywiste, żeby było im dozwolone tworzyć quorum synagogi, nawet w mniej restrykcyjnym środowisku, jakim była Macedonia. Wykaz dowodowy, że kobiety sponsorowały tam synagogi diaspory, nie pozwala na inną konkluzję̧4.

Zauważmy zatem, że Lidia czuła się upoważniona, być może na skutek wyzwoleńczego działania Ewangelii, do wystąpienia przeciwko żydowskiemu obyczajowi, nie tylko zwracając się do Pawła publicznie, lecz także zapraszając go z tymi, którzy byli z nim, całkiem obcymi ludźmi, do przyjścia i zamieszkania w jej domu [16, 15]. Mamy tu opowiadanie, jak Ewangelia uwalnia kobiety z dawniejszych ograniczeń, wyznaczając im nowe role, nawet jako założycielki członkinie nowych chrześcijańskich kościołów domowych.

Być może, z uwagi na to, że kobiety w Macedonii były często znane z podejmowania przywódczych ról w społeczeństwie, nawet już w czasach przed Aleksandrem Wielkim, wystąpienie Lidii w nowej roli mogłoby być mniejszą niespodzianką w większej społeczności. Jeśli jednakowoż byliby w Filippi mężczyźni żydzi, jej przywódcza rola tamże byłaby dla nich zaskoczeniem. Lidia zaś przyjąwszy słowo Pana od Pawła, została ochrzczona, przyjęła znak przymierza nowej religii, coś czego nie mogłaby otrzymać w judaizmie [obrzezanie kobiet nie było w nim praktykowane]. Tak przedstawia Łukasz historię ukazującą, jak Ewangelia jest dla wszelkich kategorii ludzi, niezależnie od ich płci, poprzedniej przynależności religijnej lub statusu społecznego.

Imię Lidia oznaczało pierwotnie osobę pochodzącą z krainy nazywanej Lidia, tzn. Lidyjkę. Gdyby ten przypadek zachodził w Dz 16, to nie znalibyśmy aktualnego imienia tej kobiety. Jednakowoż, co miało już wcześniej miejsce u Horacego [Carmen 1,8], Lidia było już też imieniem osobowym; a ponieważ kraina Lidii została wchłonięta przez prowincję o nazwie $A z j a$, kiedy ta historia się dzieje, Lidia jest tu najprawdopodobniej imieniem własnym osoby.

Miasto Tiatyra istniało w czasach Pawła $\mathrm{i}$ już dawno było znane jako centrum wytwarzania farby do purpury. Czytamy w Dz 16, 14, że Lidię

${ }^{4}$ Por. Flp 4, 15-16. 18. W tej pomocy okazanej Pawłowi Lidia mogła odegrać jakąś rolę. 
łączyły z jej miastem pochodzenia stosunki handlowe; sprzedawała tkaniny farbowane tą królewską barwą. Prawdopodobnie Lidia była kobietą finansowo niezależną, a businesswoman - powiedzielibyśmy dzisiaj. Homer wymienia w Iliadzie [4. 141-42] dwie kobiety, które były znane dzięki sztuce farbowania purpury w Lidii, tak widocznie biblijna Lidia była daleką następczynią kobiet trudniących się tam tym rzemiosłem i handlem. Najprawdopodobniej przybyła ona do Filippi, miasta będącego rzymską kolonią, aby sprzedawać swoje dobra tamtejszej bogatej klienteli ${ }^{5}$.

Data wspomnienia św. Lidii - 3 sierpnia - została wyznaczona dowolnie przez Baroniusza ${ }^{6}$, który wprowadził ją do Martyrologium Romanum w roku 15847. W Niemczech obchodzą chrześcijanie w roku 2003 Święto Biblii. W związku z tym donosiła tamtejsza prasa katolicka ${ }^{8}$, że 14 czerwca obchodzono w Neuhausen Święto Lidii na cześć pierwszej chrześcijanki Europy; wszystko było na modłę grecką - ubiory, potrawy, jak 2000 lat temu u Lidii w gościnie, dla przypomnienia sceny z Dz 16 . W całej imprezie wyeksponowano jej cnotę gościnności, i słusznie. Czy nie zasługiwałaby na jakieś choćby skromne uwzględnienie w liturgii ta święta Europejka, wobec ogłoszenia przez Jana Pawła II św. Teresy Benedykty od Krzyża / Edyty Stein [9 VIII], św. Brygidy Szwedzkiej [23 VII], św. Katarzyny ze Sieny [29 IV] współpatronkami kontynentu europejskiego [1 X 1999]?

\footnotetext{
${ }^{5}$ Zob. Ben Witherington, Women in the Earliest Churches, Cambridge 1988.

${ }^{6}$ Baronius Cesare COr, kard. [1538-1607], historyk Kościoła.

${ }^{7}$ H. Fros, F. Sowa, Księga imion i świętych, tom 3 (H-Ł), Kraków 1998, kol. 623-624.

${ }^{8}$ Tag des Herrn, Nr 26 z 29 VI 2003.
} 